\title{
TRACE METAL CONCENTRATION AND SPECIATION IN STORM WATER RUNOFF ON IMPERVIOUS SURFACES
}

\author{
Enrico MANCINELLI ${ }^{a}$, Edita BALTRĖNAITE $\dot{E}^{\mathrm{b}}$, Pranas BALTRĖNAS ${ }^{\mathrm{b}}$, Dainius PALIULIS ${ }^{\mathrm{b}}$, \\ Giorgio PASSERINI', Åsgeir R. ALMÅS ${ }^{\mathrm{d}}$ \\ ${ }^{a}$ Faculty of Civil Engineering, Università Politecnica delle Marche, via Brecce Bianche 12, 60131 Ancona, Italy \\ ${ }^{b}$ Department of Environmental Protection, Vilnius Gediminas Technical University, \\ Sauletekio al. 11, 10223 Vilnius, Lithuania \\ 'Department of Industrial Engineering and Mathematics Sciences, Università Politecnica delle Marche, \\ via Brecce Bianche 12, 60131 Ancona, Italy \\ ${ }^{d}$ Department of Plant and Environmental Sciences, Norwegian University of Life Science, \\ P.O. Box 5003, N-1432 Ås, Norway
}

Submitted 20 Dec. 2013; accepted 13 Jun. 2014

\begin{abstract}
Urban storm water runoff (USWR) often transports various trace metals, affecting the quality of receiving waters. Metal concentration and speciation in USWR were investigated by analysing data collected during a storm event on 19 July 2012. USWR samples were taken from a low-traffic intensity road, a pathway in a car-free pedestrian zone, and a galvanized metal roof located in the area of Vingio Park in the city of Vilnius, Lithuania. The metals were mostly in the insoluble form at all three sites, being more than $80 \%$ of the total amount measured, irrespective of the water quality characteristics and types of surface area. The partitioning coefficient (log Kd) of trace metals decreases in the order $\mathrm{Zn}>\mathrm{Cu} \approx \mathrm{Mn} \approx \mathrm{Pb}>>\mathrm{Cd}$. The USWR types characterized by a higher $\mathrm{pH}$ or dissolved organic carbon (DOC) concentration produced a higher fraction of $\mathrm{Cd}, \mathrm{Mn}, \mathrm{Pb}$, and $\mathrm{Zn}$ bound to fulvic acids (FA).
\end{abstract}

Keywords: storm water runoff, trace metals, macro elements, speciation, partitioning, water pollution, WHAM.

\section{Introduction}

Storm water runoff (SWR) from impervious surfaces can be considered a non-point source of water pollution (NPSWP) since the sources of pollution are diffuse and difficult to control. Traffic, industry and energy emissions (e.g. power stations), erosion of building materials and transportation are among the main sources of pollutants in SWR (Sabin et al. 2005; Göbel et al. 2007; Milukaitè et al. 2008).

Urban storm water runoff (USWR) is being recognized as a leading source of pollutants to receiving waters (Shaw et al. 2006). In urban areas, SWR represents a major environmental issue because it can be affected by elevated concentrations of trace metals (e.g. $\mathrm{Cd}, \mathrm{Cu}, \mathrm{Ni}, \mathrm{Pb}$ and $\mathrm{Zn}$ ) deteriorating the quality of water basins (Van Metre, Mahler 2003; Prestes et al. 2006; Brown, Peake 2006; Tiefenthaler et al. 2008). Of the trace metals typically found in $\mathrm{SWR}, \mathrm{Cd}, \mathrm{Cu}, \mathrm{Pb}$, and $\mathrm{Zn}$ are the major concern
(Van Metre, Mahler 2003; Weiss et al. 2006; Kayhanian et al. 2008). Various studies have identified the corrosion of galvanized steel roofing materials and metal drainage elements (e.g. gutters, downspouts and steel sheets) as a main source of $\mathrm{Cd}, \mathrm{Pb}$, and $\mathrm{Zn}$ in SWR from roof surfaces (Van Metre, Mahler 2003; Chang et al. 2004; Rocher et al. 2004; Brown, Peake 2006; Lamprea, Ruban 2008; Ogburn et al. 2012). Vehicle exhaust emissions, the corrosion of galvanized safety barriers, wear and tear from tyres and brakes are the primary sources of $\mathrm{Cd}, \mathrm{Cr}, \mathrm{Cu}, \mathrm{Pb}$, and $\mathrm{Zn}$ in SWR from road surfaces (Legret, Pagotto 1999 cited in Rule et al. 2006; Adachi, Tainosho 2004).

Many parameters affect metal concentrations, behaviour and fate in SWR. Differences in land use and surface characteristics (e.g. surface roughness or material composition) result in a variety of trace metal concentrations and their presence in SWR (Dierkes et al. 2005; Gnecco et al. 2008; Wicke et al. 2012). The processes governing

Corresponding author: Enrico Mancinelli

E-mail: enrico.mancinelli@alice.it 
metal partitioning depend on parameters such as surface characteristics (Göbel et al. 2007), rainfall pH, runoff residence time, and solid characteristics (e.g. particle size) (Sansalone, Ying 2008). Rainfall intensity and rainfall volume are important factors that influence the trace metal wash-off from impervious surfaces (Sonzogni et al. 1980 cited in Herngren et al. 2005). Wet atmospheric deposits are subject to significant evolutions due to transport and runoff from different urban surfaces. According to Pitt (1987 cited in Pitt et al. 1995), the relative importance of the contribution of organic and inorganic pollutants from source areas is a function of the area characteristics, pollutant wash-off potential, and the rainfall characteristics.

Municipalities should define and adopt the best available techniques (BAT) in order to minimize pollutant input to receiving water basins. In order to identify possible reduction measures or better treatment management it is necessary to define the sources, load and behaviour in the aquatic system of priority substances. The assessment of the partitioning of metals between the solid and liquid phases is an important factor in assessing the fate and bioavailability of the metals in receiving waters (Ciffroy et al. 2003). Regarding the toxicity of an element, its bioavailability is more important than its total concentration. Given the fact that the chemical form or speciation of metals affects bioavailability, and hence toxicity, it is important to determine the concentration of free metal ions, inorganic and organic complexes, and organometallic compounds rather than the total concentration of elements. For example, at the same concentration of total metal such as $\mathrm{Cu}$, $\mathrm{Cd}$, and $\mathrm{Pb}$, the uncomplexed ionic forms are much more toxic than the complexed ones (Bricker 1999). In order to determine the real available trace metal fractions, the adoption of speciation modelling should involve the determination of trace metal concentration together with the physico-chemical properties of the water (e.g. major ions, organic metal-complexing agents, $\mathrm{pH}$, etc.) (Peijnenburg, Jager 2003). According to Comber and Georges (2008), the bioavailability of $\mathrm{Cu}$ and $\mathrm{Zn}$ depends on $\mathrm{pH}$, Ca concentration, and the presence of dissolved organic matter (DOM). If the physicochemical properties of the water are not determined, the evaluation of metal bioavailability and toxicity is hard to define. Compared to the extensive literature on trace metals in SWR from roof and road surfaces, the presence of major ions (e.g. $\mathrm{Ca}^{2+}, \mathrm{K}^{+}$and $\mathrm{Mg}^{2+}$ ) has been poorly investigated (Göbel et al. 2007).

The study of SWR pollution is in its infancy in Lithuania and common water parameters (e.g. biochemical oxygen demand (BOD), suspended solids (SS), and $\mathrm{pH}$ ) are usually the subject of research (Karlavičienè et al. 2009). To our knowledge, only Milukaitè et al. (2010) have investigated trace metal (e.g. $\mathrm{Cd}, \mathrm{Cu}, \mathrm{Pb}, \mathrm{Zn}$ ) concentrations in both the soluble and insoluble forms in SWR in the area of Vilnius city.
The purpose of the current field study was to collect data on dissolved and SS-bound trace metals $(\mathrm{Cd}, \mathrm{Cr}, \mathrm{Cu}$, $\mathrm{Mn}, \mathrm{Ni}, \mathrm{Pb}$ and $\mathrm{Zn}$ ) as well as macro elements $(\mathrm{Ca}, \mathrm{K}$, and $\mathrm{Mg}$ ) that can compete in binding to humic substances in USWR from surfaces characterized by different material composition and usage. The information obtained was used to evaluate and compare metal concentrations and speciation at each site. We first hypothesize that $\mathrm{pH}$ and DOM concentration in USWR varies between the investigated sites. Moreover we hypothesize that a high $\mathrm{pH}$ and DOM concentration reduces the free metal ion activity of eroded trace metals, and hence increases their mobility as metal-DOM complexes. This study may have implications for the operational choices of storm water treatment best management practices (BMPs) for particle separation or treatment of the soluble fraction in order to avoid the water quality impairment of receiving waters.

\section{Materials and methods}

\subsection{Sampling sites}

The sampling sites, selected to represent an urban environment and to allow the assessment and comparison of the metal concentration, partition and speciation in USWR from different impervious surfaces, were located in the area of the town named "Vingio Park", situated on the North-Western side of the city of Vilnius, on a bend of the river Neris $\left(54^{\circ} 41^{\prime} 0^{\prime \prime} \mathrm{N}, 25^{\circ} 14^{\prime} 23^{\prime \prime} \mathrm{E}\right.$ ) (Fig. 1). The soil parent material in the study area consists of Holocene alluvial deposits of fine sands (Zinkute et al. 2011).

Given the fact that the location of the sampling sites is in a metropolitan area and not far from a heavily industrialized zone, atmospheric deposition is assumed to be an important trace metal source for USWR. In 2000, road transport was the largest source (97\%) of the emissions into the atmosphere generated by mobile pollution sources in Lithuania (Baltrènas et al. 2004). According to Zavadskas et al. (2007), vehicle emissions are mainly responsible for air pollution in the city of Vilnius. In addition, Milukaitè et al. (2008) have observed a close relationship between $\mathrm{Cd}, \mathrm{Cu}, \mathrm{Pb}, \mathrm{Zn}$ and oil products in atmospheric deposition, suggesting that traffic represents the major source of pollution that can affect the chemical composition of atmospheric depositions in Vilnius. In the street zone, the deposition of $\mathrm{Cd}, \mathrm{Cu}, \mathrm{Pb}$, and $\mathrm{Zn}$ is calculated to be about $20,40,29$, and $25 \%$ of the total trace metals that deposit yearly in Vilnius.

USWR samples were collected from the downspouts of a roof surface of a building located in M.K. Čiurlionio Street No. 100, next to the amphitheatre of Vingio Park (i.e. sampling site number 1 in Fig. 1). It should be noted that the building was constructed a few years ago and the gutters, the downspouts and the roofing material are all made of galvanized metal. 


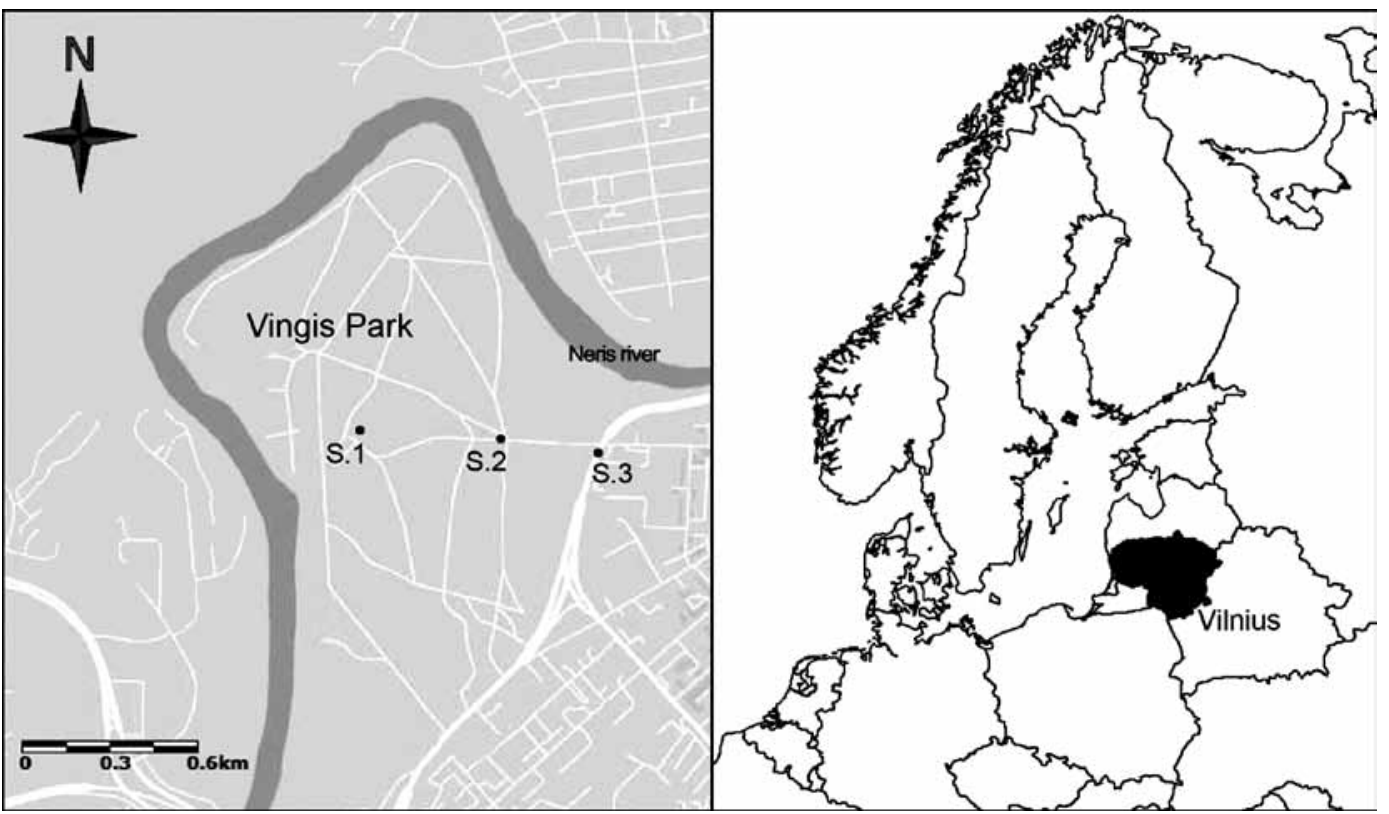

Fig. 1. Location of Lithuania in the Baltic Sea region. Location of the sampling sites in the area of Vingio Park, in Vilnius, Lithuania. The dots indicate the sampling points along M.K. Čiurlionio St.: S.1 is the roof site; S.2 is the pathway site; S. 3 is the road site

Sampling site number 2 (Fig. 1) is a pathway in a carfree pedestrian zone inside the park, in proximity to the entrance from M.K. Čiurlionio Street. No point sources of trace metals pollution were identified in proximity to this sampling site.

The road USWR samples were taken in M. K. Čiurlionio Street (i.e. sampling site number 3 in Fig. 1), a lowtraffic intensity road that is used only by people who go to Vingio Park, from the flyover that crosses over the heavily trafficked road named Geležinio Vilko Street, which is the main urban speedway in Vilnius, with a measured transport flow of about 140 thousand cars per 24 hours (Jarasuniene 2010). It should be noted that, in that area, Geležinio Vilko Street is a cut road (i.e. a road that is below ground level), thus a street canyon effect could be originated hence affecting the air circulation and limiting the dispersion of the smog.

\subsection{Sampling of urban storm water runoff}

The sampling was conducted during a storm event on 19 July 2012. The USWR sampling consisted in collecting SWR manually by taking grab samples directly from drainage flow (Spurlock 1999). All the USWR samples were collected by multiple sampling (about $5 \mathrm{~L}$ ) in pre-cleaned polyethylene (PE) bottles; samples were collected until $25 \mathrm{~L}$ volume were obtained resulting in a single, composite sample for each site. After collection, the samples at each site were sealed in pre-cleaned PE bottles and stored at a temperature of $4{ }^{\circ} \mathrm{C}$ in darkness until analysis. The sampling technique, preservation and handling of the water samples were carried out in accordance with the following methodology: ISO 5667-1: Water quality - Sampling Part 1: Guidance on the design of sampling programmes and sampling techniques and ISO 5667-3: Water qualitySampling - Part 3: Guidance on the preservation and handing of water samples.

SWR measurements were taken at the time of sampling using the volumetric time-based Bucket method: a bucket and a stop-watch were used during the storm event to measure the runoff flow-rate as described in Spurlock (1999). The flow-rate of the runoff water showed a great variability between the three sampling sites, with the rate of fluid flow on the pathway $\left(0.42 \mathrm{~L} \mathrm{~s}^{-1}\right)$ and the road surface $\left(0.25 \mathrm{~L} \mathrm{~s}^{-1}\right)$ being, respectively, 8 and 5 times greater than on the roof surface $\left(0.05 \mathrm{~L} \mathrm{~s}^{-1}\right)$.

Table 1 . Daily precipitation in the period $13-19 / 07 / 12$. The daily precipitation amount recorded when the urban storm water runoff samples were taken is highlighted in bold

\begin{tabular}{lccccccc}
\hline \multicolumn{1}{c}{ Date } & $13-7$ & $14-7$ & $15-7$ & $16-7$ & $17-7$ & $18-7$ & $\mathbf{1 9 - 7}$ \\
\hline $\begin{array}{l}\text { Daily } \\
\text { precipitation } \\
(\mathrm{mm})\end{array}$ & 0 & 1.3 & 0.2 & 0 & 7.1 & 3.4 & $\mathbf{6 . 6}$ \\
\hline
\end{tabular}

The meteorological data, from 13 to 19 July 2012, recorded the precipitation by means of the rain gauge of the Lithuanian Hydrometeorological Service; the rain gauge station is located in the district of Vilnius, in the town of Traku Voke (54 37' 33.571" N, $25^{\circ} 6^{\prime} 25.430^{\prime \prime}$ E). This is in proximity to the city of Vilnius and not far from the sampling sites. The storm event of 19 July 2012 was characterized by a dry period lasting less than 1 day (Table 1). The observed rainfall pattern during the previous 
days suggests that the length of the dry period was short for a consistent pollutant build-up due to the dry deposition of solids.

\subsection{Physical and chemical preparation of the urban storm water runoff samples}

Regarding the preparation of the USWR samples, a portion of the samples was thoroughly mixed and homogenized in 4 pre-cleaned PE buckets, with a volume of $10 \mathrm{~L}$ each, in order to ensure an appropriate homogeneity and create a single representative sample of USWR from each sampling site. Each well-mixed subsample was withdrawn from the bucket using a graduated cylinder.

Prior to analysis, the USWR samples were separated into solid and liquid phases. A measured volume of USWR sample was filtered in order to determine the metals adsorbed onto SS. The concentration of SS was determined by vacuum filtration through pre-weighted glass fibre Whatman GF/693 filters (Whatman International Ltd., Maidstone, UK) characterized by an average pore size of $1.2 \mu \mathrm{m}$, and a fast rate of filtration; after filtration, solid particles remaining in the filter paper were dried at a temperature of $105^{\circ} \mathrm{C}$ and re-weighted to quantify the dry weight (DW) of SS.

The filtrate obtained in the first filtering process was subsequently filtered in order to detect the presence of dissolved metal ions and dissolved organic carbon (DOC) at each sampling site. For this purpose, sterile Acrodisc syringe filters with a Supor (hydrophilic polyethersulfone) membrane and pore size $0.45 \mu \mathrm{m}$, (Pall Corporation) were used.

Regarding the concentration of metals adsorbed onto SS, the insoluble fraction of USWR on the filter was digested prior to flame atomic absorption spectrophotometry (FAAS) or graphite furnace (GFAAS) analysis. In order to determine trace metal concentration, a rapid and efficient method of sample decomposition is microwave digestion (Peijnenburg, Jager 2003). This enables a more rapid extraction of the metals from the particles compared to traditional techniques; it prevents the loss of volatile elements and also avoids contamination from the environment. The insoluble fraction of the USWR on the filter was digested for metal analysis using an Ethos 900 Milestone Microwave digestion system. The digestion process consisted in mixing each sample with $3 \mathrm{~mL}$ of $\mathrm{HNO}_{3}(65 \%)$ and $9 \mathrm{~mL}$ of $\mathrm{HCl}(37 \%)$; subsequently the samples were poured into special vessels and then placed in a Milestone ETHOS digester and heated for 43 minutes. The resulting solution was poured into a $50 \mathrm{~mL}$ flask and the volume was made up to $50 \mathrm{~mL}$ with deionized water (Butkus, Baltrenaite 2007; Pundyte et al. 2011). In order to remove any possible presence of metal on the walls of the vessels, all the vessels were accurately rinsed with deionized water.

\subsection{Chemical analysis of urban storm water runoff}

As regards water chemistry characterization, laboratory tests of USWR samples were performed in the laboratories of the Research Institute of Environmental Protection (Vilnius Gediminas Technical University). The pollution parameters studied were: electric conductivity (EC), $\mathrm{pH}$, SS, DOC, trace metals (Cd, $\mathrm{Cu}, \mathrm{Cr}, \mathrm{Mn}, \mathrm{Ni}, \mathrm{Pb}$, and $\mathrm{Zn}$ ) and macro elements ( $\mathrm{Ca}, \mathrm{K}, \mathrm{Mg})$.

$\mathrm{EC}$ and $\mathrm{pH}$ were determined by analysing unfiltered USWR samples. The $\mathrm{pH}$ of USWR samples was determined using a $\mathrm{pH}$-meter with an electronic glass electrode (SevenMulti ion/pH/ORP module Mettler Toledo); before the determinations, the $\mathrm{pH}$-meter was calibrated with buffer solutions at $\mathrm{pH} 4,7$, and 11 (Merck, Darmstadt, Germany); the resulting calibration curve was determined via a linear regression line. $\mathrm{pH}$ measurements were carried out in accordance with the methodology described in ISO 10523: Water quality - Determination of $p H$. EC was measured by a conductivity-meter (inoLab Cond 740 WTW) in accordance with the methodology of ISO 7888: Water quality - Determination of electrical conductivity.

The DOC in USWR samples filtered through a syringe (pore size $0.45 \mu \mathrm{m}$, Pall Corporation) was determined by employing a total organic carbon (TOC) analyser (Shimadzu-V CSN) at $900^{\circ} \mathrm{C}$. For each sampling site, three sub-samples of $40 \mathrm{~mL}$ volume were analysed. In this work, the DOC is equivalent to TOC because the USWR samples were first filtered; syringe filters with a pore size $0.45 \mu \mathrm{m}$ (Pall Corporation) were used for this purpose.

The analysis of dissolved trace metals and macro elements in the solution phase was performed after a syringe filtration through a $0.45 \mu \mathrm{m}$ Acrodisc filter. The concentration in solution was measured using flame atomic absorption spectrophotometry (FAAS) (210 VGP atomic absorption spectrophotometer Buck Scientific); when the concentration of metals such as $\mathrm{Cd}, \mathrm{Cu}, \mathrm{Mn}$, and $\mathrm{Pb}$ was too low to be detected accurately by FAAS, a graphite furnace (GFAAS) was used (Baltrenaite et al. 2010; Butkus, Baltrenaite 2007). The detection limits of $\mathrm{Ca}, \mathrm{K}, \mathrm{Mg}, \mathrm{Mn}$, $\mathrm{Ni}, \mathrm{Zn}, \mathrm{Pb}, \mathrm{Cu}$ and $\mathrm{Cr}$ were $0.3 ; 0.3 ; 0.05 ; 0.2 ; 0.2 ; 0.04 ; 0.2$; 0.1 and $0.2\left(\mathrm{mg} \mathrm{L}^{-1}\right)$ using FAAS; the GFAAS detection limit of $\mathrm{Cd}, \mathrm{Cu}, \mathrm{Mn}$ and $\mathrm{Pb}$ was $0.002\left(\mathrm{mg} \mathrm{L}^{-1}\right)$. All the procedures were carried out in accordance with the methods mentioned in ISO 8288: Water quality - Determination of cobalt, nickel, copper, zinc, cadmium and lead - Flame atomic absorption spectrometric methods; ISO 9174: Water quality - Determination of chromium - Atomic absorption spectrometric methods; ISO 9964-2: Water quality - Determination of sodium and potassium - Part 2: Determination of potassium by atomic absorption spectrometry and ISO 7980: Water quality - Determination of calcium and magnesium - Atomic absorption spectrometric method. 
The concentration of adsorbed metals in SS was measured using FAAS or GFAAS methods in accordance with ISO 11047: Soil quality - Determination of cadmium, chromium, cobalt, copper, lead, manganese, nickel and zinc in acqua regia extracts of soil - Flame and electrothermal atomic absorption spectrometric methods. This standard specifies ways to determine metal concentration in aqua regia extracts of soil through flame and electrothermal atomic absorption spectrometric methods. As regards the determination of macro elements adsorbed onto SS by FAAS, the samples were analysed under optimum analytical conditions setting the instrumentation according to Buck Scientific device description.

\subsection{Quality assurance}

Standard solutions of $\mathrm{Ca}, \mathrm{Cd}, \mathrm{Cr}, \mathrm{Cu}, \mathrm{K}, \mathrm{Mg}, \mathrm{Mn}, \mathrm{Ni}, \mathrm{Pb}$ and $\mathrm{Zn}$ (1000 ppm) (Buck Scientific, USA) were used for FAAS or GFAAS calibration. All the chemicals used in this study were of analytical grade and solutions were prepared with deionized water. Concentrated nitric (65\%) and hydrochloric (35\%) acid was employed for the digestion of the samples.

In order to monitor for possible contaminations resulting from the sample preparation procedure, a reagent blank was prepared for each of the digestion procedure, following the entire sequence of steps as described above for sample preparation in each case.

\subsection{WHAM/Model VII, version for waters}

For each sampling site, metal speciation in USWR was simulated using the chemical speciation program WHAM/ Model VII based on WHAM (Tipping 1994). WHAM7 for waters includes different submodels such as the humic ion-binding Model VII, a surface complexation model simulating ion-binding to oxides of aluminum, iron, manganese and silicon, a model for inorganic solution chemistry speciation, and a model for cation exchange on clays. The model assumes that metal species are at chemical equilibrium and it does not consider kinetically-controlled reactions. It is based on the discrete-site/electrostatic formulation of the interactions of protons and metals with humic substances; in describing binding sites for metals it adopts a distributional approach.

\subsection{WHAM modelling}

The speciation of the detected trace metals $(\mathrm{Cd}, \mathrm{Cu}, \mathrm{Mn}$, $\mathrm{Pb}$, and $\mathrm{Zn}$ ) and major elements $(\mathrm{Mg}, \mathrm{K}$, and $\mathrm{Ca}$ ) in USWR was calculated using WHAM7 (Tipping et al. 2011) for waters. The values of $\mathrm{pH}$, fulvic acids (FA), SS and metal concentration were input as measured in the USWR analysis (Table 2). As regards the solute type adopted for the modelling, the concentration in USWR of metals in soluble form (syringe filtered water, $0.45 \mu \mathrm{m}$ pore size), determined with FAAS or GFAAS analysis, was identified as total dissolved concentration. A temperature of $15^{\circ} \mathrm{C}$ and no $\mathrm{CO}_{2}$ partial pressure were set for all USWR types.

Metal binding to DOM in WHAM assumes metal binding to acid groups on humic (HA) and fulvic acids (FA). We assumed that the DOM has the binding properties of "default" FA, and that the DOM is $50 \%$ made up of carbon. DOM was considered "colloidal" and, as suggested in the work by Dwane and Tipping (1998), it was assumed to consist of a fraction of $50 \%$ active fulvic acid (\% aFA) for proton/metal binding and a fraction of $50 \%$ that is inert as regards ion-binding. The calculated metal concentrations in the "aqueous phase" as defined in WHAM, are hereafter reported as soluble. This includes those in true solution and metals in the diffuse layers of colloidal phases (here, the FA).

The Debye-Hückel equation for the activity correction of the solution equilibrium calculation and the default database of stability constants were adopted. The model outputs were analysed to provide the following results for each USWR type and metal: fractions of free metal ions relative to total dissolved metals, fraction of truly dissolved metal, fraction of metal bound to colloids (represented by FA).

\subsection{Statistics and calculation}

Statistical analysis was carried out using GNU PSPP Statistical Analysis Software (PSPP, n.d.). For the descriptive statistics of element concentrations in the USWR, values of the mean, median, standard deviation and coefficient of variance $(\mathrm{CV})$, were calculated for each element detected from the three sites. In order to evaluate the correlation between the detected elements from each site and to determine if the means of concentrations were affected by

Table 2. WHAM modelling input data for $\mathrm{pH}$, dissolved organic carbon (DOC), suspended solids (SS), and metal concentration as measured in the urban storm water runoff analysis. [] tot diss.: total dissolved concentration of trace metals and macro elements

\begin{tabular}{|c|c|c|c|c|c|c|c|c|c|c|c|}
\hline & $\begin{array}{l}{[\mathrm{Mg}]_{\text {tot diss }}} \\
\left(\mathrm{mol} \mathrm{L}^{-1}\right)\end{array}$ & $\begin{array}{l}{[\mathrm{K}]_{\text {tot diss }}} \\
\left(\mathrm{mol} \mathrm{L}^{-1}\right)\end{array}$ & $\begin{array}{l}{[\mathrm{Ca}]_{\text {tot diss }}} \\
\left(\mathrm{mol} \mathrm{L}^{-1}\right)\end{array}$ & $\begin{array}{l}{[\mathrm{Mn}]_{\text {tot diss }}} \\
\left(\mathrm{mol} \mathrm{L}^{-1}\right)\end{array}$ & $\begin{array}{l}{[\mathrm{Cu}]_{\text {tot diss }}} \\
\left(\mathrm{mol} \mathrm{L}^{-1}\right)\end{array}$ & $\begin{array}{l}{[\mathrm{Zn}]_{\text {tot diss }}} \\
\left(\mathrm{mol} \mathrm{L}^{-1}\right)\end{array}$ & $\begin{array}{l}{[\mathrm{Cd}]_{\text {tot diss }}} \\
\left(\mathrm{mol} \mathrm{L}^{-1}\right)\end{array}$ & $\begin{array}{l}{[\mathrm{Pb}]_{\text {tot diss }}} \\
\left(\mathrm{mol} \mathrm{L}^{-1}\right)\end{array}$ & $\mathrm{pH}$ & $\begin{array}{c}\mathrm{SS} \\
\left(\mathrm{g} \mathrm{L}^{-1}\right)\end{array}$ & $\begin{array}{c}\mathrm{DOC} \\
\left(\mathrm{mg} \mathrm{L}^{-1}\right)\end{array}$ \\
\hline Roof & $4.06 \times 10^{-6}$ & - & $2.86 \times 10^{-4}$ & $2.71 \times 10^{-7}$ & - & $1.11 \times 10^{-6}$ & $2.4 \times 10^{-8}$ & $2.9 \times 10^{-3}$ & 6.9 & 0.038 & 3.36 \\
\hline Pathway & $2.62 \times 10^{-5}$ & $4.53 \times 10^{-5}$ & $1.68 \times 10^{-4}$ & $3.84 \times 10^{-7}$ & - & $2.02 \times 10^{-6}$ & $1.87 \times 10^{-8}$ & $5.8 \times 10^{-3}$ & 7.3 & 0.074 & 6.4 \\
\hline Road & $2.44 \times 10^{-5}$ & $1.24 \times 10^{-5}$ & $3.57 \times 10^{-5}$ & $3.39 \times 10^{-7}$ & $5.04 \times 10^{-8}$ & $8.31 \times 10^{-7}$ & $4.09 \times 10^{-8}$ & $4.6 \times 10^{-3}$ & 8.1 & 0.135 & 3.86 \\
\hline
\end{tabular}


the different sampling site locations, Pearson's correlation coefficients were calculated; values of $\mathrm{p}<0.05$ and $<0.01$ were regarded as significant.

The metal element partitioning between the dissolved phase and SS was determined in terms of the partition coefficient ( $\left.\mathrm{Kd}, \mathrm{L} \mathrm{kg}^{-1}\right)$ and was calculated according to the following equation:

$$
K d=\frac{C s}{C w},
$$

where: $C s\left(\mathrm{mg} \mathrm{kg}^{-1} \mathrm{DW}\right)$ is the ratio between metal mass normalized to the dry mass of SS; $C w\left(\mathrm{mg} \mathrm{L}^{-1}\right)$ denotes the metal concentration in the solution phase.

Blank sample analysis showed that the mean concentration of elements such as $\mathrm{Ca}\left(0.70 \mathrm{mg} \mathrm{L}^{-1}\right), \mathrm{Mg}$ (0.065 mg L $\left.{ }^{-1}\right), \mathrm{Cu}\left(0.052 \mathrm{mg} \mathrm{L}^{-1}\right), \mathrm{Cr}\left(0.241 \mathrm{mg} \mathrm{L}^{-1}\right), \mathrm{Pb}$ (0.011 $\left.\mathrm{mg} \mathrm{L}^{-1}\right)$, and $\mathrm{Zn}\left(0.156 \mathrm{mg} \mathrm{L}^{-1}\right)$ was above the detection limit. Therefore, for the computation of the concentration of metals in suspended solids $C\left(\mathrm{mg} \mathrm{kg}^{-1} \mathrm{DW}\right)$, a correction was applied by subtracting the mean concentration detected in the blank analysis $B\left(\mathrm{mg} \mathrm{L}^{-1}\right)$ from the one obtained in the analysis of the digested filters $A$ $\left(\mathrm{mg} \mathrm{L}^{-1}\right)$, as follows:

$$
C=\frac{(A-B) \cdot D \cdot V}{m},
$$

where: $D$ is the dilution factor; $V$ is the final volume $(\mathrm{mL})$; $m$ is the suspended solid mass ( $\mathrm{g}$ ).

It should be noted that a small mass of SS may lead to an overestimation of the metal concentration in SS. Comparisons of the roof USWR data showed that the sample with a mass of SS from 4 to 9 times smaller than the other three samples had much higher metal concentrations, up to one order of magnitude. Therefore, in order to have more homogeneous data and not to overestimate the concentration of metals in SS in the roof USWR, of the four samples analysed the one with the smallest mass of SS was not considered for the evaluation of metal mass concentration.

\section{Results and discussion}

\subsection{Analysis of urban storm water runoff chemistry}

The trace metal Maximum Allowable Concentrations (MACs) for the environment are provided by the Order of the Minister of the Environment of Lithuania No. D1-236 of 17 May 2006 on Wastewater Management Regulation and its subsequent amendments. Because of the ongoing restructuring of the European Community water policy, the Lithuanian Wastewater Management Regulation has been amended several times. As regards trace metals, the amendment made by the Order of the Minister of Environment of Lithuania No. D1-416 of 18 May 2010 complies with Directive 2008/105/EC. The trace metals (e.g. $\mathrm{Cr}, \mathrm{Cu}$, and $\mathrm{Zn}$ ) that are not in the list of Directive 2008/105/EC have MAC limits that are set by Lithuanian legislation.

Compared with the Lithuanian MAC limits for the environment, none of the USWR samples collected from the three sites contained amounts of dissolved $\mathrm{Cd}, \mathrm{Cr}, \mathrm{Cu}$, $\mathrm{Pb}, \mathrm{Ni}$, and $\mathrm{Zn}$ (Table 3 ) in harmfully high concentrations.

Table 3. The dissolved trace metal concentrations detected in the urban storm water runoff samples compared to the trace metal Maximum Allowable Concentration (MAC) limits for the environment according to the Order of the Minister of the Environment of Lithuania No. D1-236 of 17 May 2006 and its

\begin{tabular}{|c|c|c|c|c|}
\hline \multirow{3}{*}{$\begin{array}{c}\text { Name } \\
\text { of substance }\end{array}$} & \multirow{3}{*}{$\begin{array}{l}\text { Maximum } \\
\text { Allowable } \\
\text { Concentration } \\
\text { (MAC) for the } \\
\text { environment } \\
\left(\mu \mathrm{g} \mathrm{L}^{-1}\right)\end{array}$} & \multicolumn{3}{|c|}{ Sampling site } \\
\hline & & Road & Roof & Pathway \\
\hline & & \multicolumn{3}{|c|}{$\left(\mu \mathrm{g} \mathrm{L}^{-1}\right)$} \\
\hline Chromium (total) & 500 & ND & ND & ND \\
\hline Copper & 500 & 3.2 & ND & ND \\
\hline Zinc & 400 & 54.33 & 72.56 & 131.9 \\
\hline $\begin{array}{l}\text { Nickel and its } \\
\text { compounds }\end{array}$ & 200 & ND & ND & ND \\
\hline $\begin{array}{l}\text { Lead and its } \\
\text { compounds }\end{array}$ & 100 & 4.57 & 2.85 & 5.76 \\
\hline $\begin{array}{l}\text { Cadmium and its } \\
\text { compounds }\end{array}$ & 40 & 4.64 & 2.72 & 2.06 \\
\hline
\end{tabular}
subsequent amendments based on Directive 2008/105/EC

Some of the investigated trace metals including $\mathrm{Cr}$ and $\mathrm{Ni}$ were not detected in the soluble phase while the concentrations of $\mathrm{Cd}, \mathrm{Cu}, \mathrm{Pb}$ and $\mathrm{Zn}$ were from 8 to 19 times, about one order of magnitude, up to 35 times and from 3 to 7 times lower than the MACs of these trace metals, respectively.

In the study by Milukaitè et al. (2010), chemical analysis of USWR from several areas of Vilnius revealed low quantities of trace metals $(\mathrm{Cd}, \mathrm{Cu}, \mathrm{Pb}, \mathrm{Zn})$ in the dissolved form with only $\mathrm{Zn}$ and $\mathrm{Cu}$ exceeding the limits set for the receiving waters in a few USWR samples. As regards the quality of USWR receiving water, in the river Neris trace metal (e.g. Cd, Cr, Cu, Ni, Pb, Zn) concentrations were found to be far lower than the MAC limits (Dudutyte et al. 2007).

The mean values of SS, DOC, EC, and $\mathrm{pH}$ for the three sampling sites are shown in Table 4. The measured $\mathrm{pH}$ was in the range from 6.9 to 8.1 in the samples taken from the roof and road surfaces, respectively. This is a similar $\mathrm{pH}$ range (7.0-8.5) to the one reported in Pitt et al. (1995) after the analysis of SWR from several source areas. This almost neutral to slightly alkaline medium reduces the concentration of free metal ions in SWR, inhibiting their desorption from SS (Bogacz 1993 cited in Milukaite et al. 2010). The pathway USWR analysis showed a twofold higher concentration of DOC, possibly originating from the surrounding forest area. 
Table 4. Summary of the data from the three sampling sites for the mean value of suspended solids (SS), dissolved organic carbon (DOC), electric conductivity (EC), and $\mathrm{pH}$

\begin{tabular}{lcccc}
\hline & $\mathrm{pH}$ & $\begin{array}{c}\mathrm{EC} \\
\left.(\mathrm{microS} \mathrm{cm})^{-1}\right)\end{array}$ & $\begin{array}{c}\mathrm{DOC} \\
\left(\mathrm{mg} \mathrm{L}^{-1}\right)\end{array}$ & $\begin{array}{c}\mathrm{SS} \\
\left(\mathrm{g} \mathrm{L}^{-1}\right)\end{array}$ \\
\hline Road & 8.1 & 75.3 & 3.86 & 0.135 \\
Roof & 6.9 & 22.7 & 3.36 & 0.038 \\
Pathway & 7.3 & 124.3 & 6.4 & 0.074 \\
\hline
\end{tabular}

The measured SS average concentration $\left(0.038 \mathrm{~g} \mathrm{~L}^{-1}\right)$ in USWR samples from the roof is in the range (0.005$0.092 \mathrm{~g} \mathrm{~L}^{-1}$ ) measured by Pitt et al. (1995) in storm water roof runoff. The rooftop produced the lowest concentration of SS, being from 2 to 4 times lower than the one detected in road and pathway USWR, respectively. This can be explained by the low roughness and the comparatively greater inclination of the zinc sheet roof surface. Therefore the particles that were on the roof could easily have been washed off this surface during the previous precipitations. The fact that SS concentration in USWR samples from the road was much lower than the average values reported in scientific literature is likely to be due to the low-density traffic of M.K. Čiurlionio St.

At all the investigated sites, the soluble concentrations of the detected constituents were much lower than the insoluble concentrations (Table 5). Analyses of metals both in SS and the dissolved form showed the predominance of the SS-bound fraction of all the detected elements with more than $80 \%$ of the total amount measured, irrespective of the water quality characteristics (e.g. pH, DOC, SS) and types of surface area. These results harmonized with the observations reported by Milukaite et al. (2010) for USWR in Vilnius. These authors reported that metals such as Cd and $\mathrm{Pb}$ were mostly in the insoluble form with more than $90 \%$ of the total amount measured. Figure 2 shows a comparison of $\log \mathrm{Kd}$ for each metal detected in the USWR from the investigated surfaces. The highest log $\mathrm{Kd}$ values were observed for $\mathrm{Zn}$ (4.9-5.6) followed by $\mathrm{Cu}, \mathrm{Mn}$, and $\mathrm{Pb}$ reflecting high affinities of these trace metals to $\mathrm{SS}$. The lowest log Kd values were found for Cd (3.1-3.5).

The ranking of adsorption potential for soil particles of the detected trace metals, with $\mathrm{Zn}$ having the highest potential, is as shown below:

$$
\mathrm{Zn}>\mathrm{Cu} \approx \mathrm{Mn} \approx \mathrm{Pb}>>\mathrm{Cd} .
$$

The partitioning coefficient values of $\mathrm{Cu}, \mathrm{Cd}, \mathrm{Pb}$, and $\mathrm{Zn}$ are consistent with values reported for surface waters by Allison, J. D. and Allison, T. L. (2005). As regards metal partitioning in the USWR from roof surfaces, there was a discrepancy between our findings and the ones reported in the study by Lamprea and Ruban (2008). These authors found that the partitioning of $\mathrm{Cd}, \mathrm{Cu}, \mathrm{Pb}$ and $\mathrm{Zn}$ was dominated by the dissolved phase due to low $\mathrm{pH}$ values

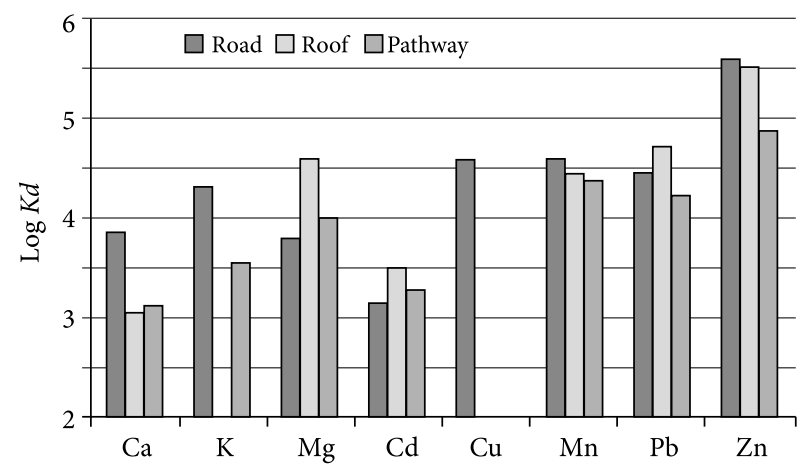

Fig. 2. Partition coefficients ( $\log \mathrm{Kd})$ calculated for macro elements and trace metals in the urban storm water runoff samples from the investigated sites

(5.1-5.8) and low SS concentrations (0.004-0.016 $\mathrm{mg} \mathrm{L}^{-1}$ ). In the present study, a higher $\mathrm{pH}$ (6.9) and higher (up to one order of magnitude) SS concentrations are likely to have limited the amount of leaching in the dissolved phase and increased the tendency of metals to partition to SS. According to Herngren et al. (2005) the reduced solubility of trace metals in SWR and the insignificant release from SS can be connected to a high $\mathrm{pH}$ and low DOC concentration.

The data from the three sampling sites for the elements analysed in soluble and insoluble forms are summarized in Table 5. Of all the detected trace metals, $\mathrm{Zn}$ concentration was the highest both in the soluble and insoluble form, whereas $\mathrm{Cd}$ concentration was the lowest for all the investigated sites. The mass concentration of $\mathrm{Zn}$ was found at levels from 1 to 3 orders of magnitude higher than $\mathrm{Pb}$ and $\mathrm{Cu}$, from 2 to 6 orders of magnitude higher than $\mathrm{Cr}$ and up to 50 times higher than Mn. In the soluble form, $\mathrm{Zn}$ was found from 10 to 25 times higher than $\mathrm{Pb}$, from 2 to 6 times higher than $\mathrm{Mn}$ and up to 60 times higher than $\mathrm{Cd}$.

Figure $3 \mathrm{a}$ shows that the concentrations of soluble metals in all samples from the investigated sites decreased in the following order, with $\mathrm{Cu}^{*}$ detected only in the road USWR:

$$
\mathrm{Zn}>\mathrm{Mn}>\mathrm{Pb}>\mathrm{Cd}>\mathrm{Cu}^{*} .
$$

The measured trace metal concentration $\left(\mathrm{mg} \mathrm{kg}^{-1}\right.$ DW) in the insoluble form (Fig. 3b) in the USWR from the different sampling sites decreased in the following order, with $\mathrm{Ni}^{*}$ detected only in the pathway USWR:

$$
\mathrm{Zn}>\mathrm{Mn}>\mathrm{Pb}>\mathrm{Cu}>\mathrm{Cr}>\mathrm{Ni}^{\star}>\mathrm{Cd} \text {. }
$$

According to Taraškevičius et al. (2008), $\mathrm{Zn}$ and $\mathrm{Pb}$ were among the main contaminants identified in the topsoil of Vilnius city recreational areas. Based on wet and dry atmospheric deposition analyses, Milukaitè et al. (2008) identified $\mathrm{Zn}$ as the trace metal with the highest annual flux to the ground surface of Vilnius. 
The USWR samples from the pathway surface exhibited the lowest concentration of $\mathrm{Zn}, \mathrm{Pb}, \mathrm{Cu}$, and $\mathrm{Cd}$ bound to SS, as expected for typical pollutants associated with vehicular traffic (Legret, Pagotto 1999 cited in Rule et al. 2006; Göbel et al. 2007) that were investigated in the USWR from a car-free pedestrian zone. Conversely, road USWR analysis showed a high concentration of $\mathrm{Zn}, \mathrm{Pb}$, $\mathrm{Cu}, \mathrm{Cr}$ and $\mathrm{Mn}$ in SS.

In a study of trace metal concentration in USWR from a district in Vilnius, the highest concentrations of $\mathrm{Cu}, \mathrm{Mn}$, and $\mathrm{Zn}$ were reported to be in the range 0.4-2.0 mg L $\mathrm{m}^{-1}, 1.3-5.1 \mathrm{mg} \mathrm{L}^{-1}$, and 0.9-12.4 $\mathrm{mg} \mathrm{L}^{-1}$, respectively (Vasarevičius et al. 2010). According to Kern et al., Sansalone and Buchberger (1992; 1997 cited in Göbel et al. 2007), trace metals coming from traffic activities are mainly found as particulate matter in SWR. Wear and tear from tyres, from brakes and the corrosion of galvanized safety barriers are the primary sources of $\mathrm{Zn}$ (Legret, Pagotto 1999 cited in Rule et al. 2006); vehicle brake emissions are major sources of $\mathrm{Cu}, \mathrm{Cr}$ and $\mathrm{Pb}$ (Adachi, Tainosho 2004). Correlations between the concentration of metals bound to SS such as Cd ( $p<0.05), \mathrm{Cu}(\mathrm{p}<0.01)$ and $\mathrm{Pb}$ as well as between $\mathrm{Cu}$ and $\mathrm{Mn}(\mathrm{p}<0.01)$ were found.

The soluble concentration of metals such as $\mathrm{Mn}, \mathrm{Pb}$, and $\mathrm{Zn}$ was found to be the highest in the USWR samples from the pedestrian zone. This is because of the higher concentrations of DOC compared to the ones measured in the USWR samples from the road and roof surfaces (Table 4). The speciation results reported below (Table 6) confirmed higher $\mathrm{Mn}, \mathrm{Pb}$ and $\mathrm{Zn}$ complexation to $\mathrm{FA}$ in the modelling of USWR from the pathway compared to the road and roof USWR whereas the fractions of Mn-FA complexes were higher in the road USWR than the pathway one. It is unclear why $\mathrm{Ni}$ was found only in the USWR from the pathway and only bound to SS (22.19 $\mathrm{mg} \mathrm{kg}^{-1} \mathrm{DW}$ ), whereas the concentration in the samples from the other sites was under the detection limit.

It should be noted that considerable amounts of trace metals were detected in the USWR from the pathway but no point sources of trace metal pollution were identified in proximity to the this sampling site. Therefore, atmospheric deposition was assumed to be a significant source of trace metal pollution for the area of Vingio Park. The observed similarity with the order of mass concentrations calculated for trace metal accumulation on the ground surface of a residential site in Vilnius in the work by Milukaite et al. (2008) suggests that atmospheric deposition played a leading role in the pollutant build-up on the investigated surfaces. In addition, a strong relation was noticed between SS-bound metals such as $\mathrm{Cu}(\mathrm{p}<0.01)$ and $\mathrm{Cd}(\mathrm{p}<0.01)$ detected in the USWR from the roof and

Table 5. Summary of the urban storm water runoff data from the three sampling sites for trace metals and macro elements analysed in soluble and insoluble forms. 9 determinations in all cases. ND not detected as the result was less than the method detection limit

\begin{tabular}{|c|c|c|c|c|c|c|c|c|c|c|c|c|c|}
\hline & & \multicolumn{4}{|c|}{ Road } & \multicolumn{4}{|c|}{ Roof } & \multicolumn{4}{|c|}{ Pathway } \\
\hline \multicolumn{2}{|c|}{ Macro elements } & Mean & Median & Std.Dev. & $\mathrm{CV}, \%$ & Mean & Median & Std.Dev. & $\mathrm{CV}, \%$ & Mean & Median & Std.Dev. & $\mathrm{CV}, \%$ \\
\hline \multirow{2}{*}{$\mathrm{Ca}$} & Soluble $\left(\mathrm{mg} \mathrm{L}^{-1}\right)$ & 1.43 & 1.42 & 0.036 & 2.5 & 11.45 & 11.45 & 0.24 & 2.1 & 6.72 & 6.64 & 0.36 & 5.3 \\
\hline & Insoluble (mg kg-1 DW) & 10611 & 12010 & 2732 & 25,7 & 12811 & 16038 & 4240 & 33.1 & 8333 & 9342 & 3124 & 37.5 \\
\hline \multirow{2}{*}{$\mathrm{K}$} & Soluble $\left(\mathrm{mg} \mathrm{L}^{-1}\right)$ & 0.48 & 0.50 & 0.105 & 21.7 & ND & & & & 1.77 & 1.77 & 0.18 & 10.0 \\
\hline & Insoluble (mg kg-1 DW) & 9983 & 11432 & 3003 & 30.1 & 10598 & 9668 & 2880 & 27.2 & 6190 & 7486 & 3363 & 54.3 \\
\hline \multirow{2}{*}{$\mathrm{Mg}$} & Soluble $\left(\mathrm{mg} \mathrm{L}^{-1}\right)$ & 0.59 & 0.59 & 0.014 & 2.4 & 0.1 & 0.098 & 0.004 & 3.7 & 0.64 & 0.65 & 0.05 & 8.1 \\
\hline & Insoluble (mg kg-1 DW) & 3527 & 4080 & 1009 & 28.6 & 3571 & 3601 & 1723 & 48.3 & 6483 & 8603 & 4609 & 71.1 \\
\hline \multicolumn{2}{|c|}{ Trace metals } & Mean & Median & Std.Dev. & $\mathrm{CV}, \%$ & Mean & Median & Std.Dev. & $\mathrm{CV}, \%$ & Mean & Median & Std.Dev. & $\mathrm{CV}, \%$ \\
\hline \multirow{2}{*}{$\mathrm{Cd}$} & Soluble $\left(\mu \mathrm{g} \mathrm{L} \mathrm{L}^{-1}\right)$ & 4.64 & 5.0 & 1.11 & 23.9 & 2.72 & 2.80 & 0.51 & 18.7 & 2.06 & 1.9 & 0.37 & 17.8 \\
\hline & Insoluble (mg kg-1 DW) & 5.49 & 6.58 & 2.09 & 38.1 & 7.82 & 7.09 & 1.65 & 21.1 & 3.87 & 3.87 & 0.78 & 20.1 \\
\hline \multirow{2}{*}{$\mathrm{Cu}$} & Soluble $\left(\mu \mathrm{g} \mathrm{L}^{-1}\right)$ & 3.2 & 3.0 & 1.01 & 31.6 & $\mathrm{ND}$ & & & & $\mathrm{ND}$ & & & \\
\hline & Insoluble (mg kg-1 DW) & 117.1 & 111.3 & 10.8 & 9.3 & 60.3 & 52.7 & 33.2 & 55.0 & 58.4 & 71.3 & 28.2 & 48.3 \\
\hline \multirow{2}{*}{$\mathrm{Cr}$} & Soluble $\left(\mu \mathrm{g} \mathrm{L}^{-1}\right)$ & $\mathrm{ND}$ & & & & ND & & & & ND & & & \\
\hline & Insoluble (mg kg-1 DW) & 44.7 & 45.6 & 11.8 & 26.4 & 36.0 & 52.0 & 29.1 & 81.0 & 41.7 & 52.1 & 24.9 & 59.7 \\
\hline \multirow{2}{*}{$\mathrm{Mn}$} & Soluble $\left(\mu \mathrm{g} \mathrm{L}^{-1}\right)$ & 18.61 & 19.3 & 2.92 & 15.7 & 14.88 & 14.7 & 2.29 & 15.4 & 21.1 & 20.8 & 4.5 & 21.3 \\
\hline & Insoluble (mg kg-1 DW) & 650 & 746 & 171 & 26.3 & 429 & 448 & 329 & 76.8 & 504 & 603 & 241 & 47.8 \\
\hline \multirow{2}{*}{$\mathrm{Ni}$} & Soluble $\left(\mu \mathrm{g} \mathrm{L}^{-1}\right)$ & $\mathrm{ND}$ & & & & ND & & & & ND & & & \\
\hline & Insoluble (mg kg-1 DW) & $\mathrm{ND}$ & & & & ND & & & & 22.2 & 22.2 & 1.1 & 5.0 \\
\hline \multirow{2}{*}{$\mathrm{Pb}$} & Soluble $\left(\mu \mathrm{g} \mathrm{L}^{-1}\right)$ & 4.57 & 3.5 & 3.06 & 66.9 & 2.85 & 3.05 & 1.69 & 59.3 & 5.76 & 6.10 & 1.14 & 19.8 \\
\hline & Insoluble (mg kg-1 DW) & 135 & 150 & 34 & 25.2 & 138 & 142 & 69 & 50.0 & 99,1 & 127 & 51 & 51.3 \\
\hline \multirow{2}{*}{$\mathrm{Zn}$} & Soluble $\left(\mu \mathrm{g} \mathrm{L}^{-1}\right)$ & 54.33 & 58.0 & 16.55 & 30.5 & 72.56 & 85.0 & 43.54 & 60.0 & 131.9 & 138.0 & 19.91 & 15.1 \\
\hline & Insoluble (mg kg-1 DW) & 20592 & 23798 & 6344 & 30.8 & 22373 & 20036 & 4265 & 19.1 & 9964 & 11605 & 5446 & 54.7 \\
\hline
\end{tabular}


road surfaces as well as between $\mathrm{Zn}(\mathrm{p}<0.01)$ and $\mathrm{Pb}(\mathrm{p}$ $<0.01$ ) detected in the USWR from the road and the pathway surfaces.

For the insoluble form of trace metals such as $\mathrm{Cd}$, $\mathrm{Pb}$, and $\mathrm{Zn}$ the highest concentrations were measured in the USWR from the roof and road surfaces (from 30 to $50 \%$, about $30 \%$ and $50 \%$ higher than $\mathrm{Cd}, \mathrm{Pb}$, and $\mathrm{Zn}$ detected in the USWR from the pathway, respectively); this may be attributed to the presence of galvanized steel materials such as safety barriers, gutters, downspouts and steel sheets that have been identified among the primary sources of $\mathrm{Zn}$ in roof and road SWR by many authors (Chang et al. 2004; Rocher et al. 2004; Brown, Peake 2006; Lamprea, Ruban 2008). Metals such as $\mathrm{Cd}$ and $\mathrm{Pb}$ are minor constituents of galvanized steel (Ogburn et al. 2012). Correlations ( $\mathrm{p}<0.01, \mathrm{p}<0.05$ ) were found between the concentration of the metals in SS detected in the USWR from the road (e.g. Pb, Cd) and roof surfaces (e.g. $\mathrm{Zn}, \mathrm{Cd}$ ), between $\mathrm{Zn}$ and $\mathrm{Cd}$ in the USWR from the roof as well as between $\mathrm{Cd}$ and $\mathrm{Pb}$ in the USWR from the road.

A prolonged contact time with water can increase the weathering and deterioration of metal materials (Ogburn et al. 2012). The observed rainfall pattern (i.e. a previous dry period of less than one day) suggests that building materials may represent an important local source of metals in USWR from the roof and road surfaces since the prolonged wet weather conditions may have promoted erosion and weathering phenomena.

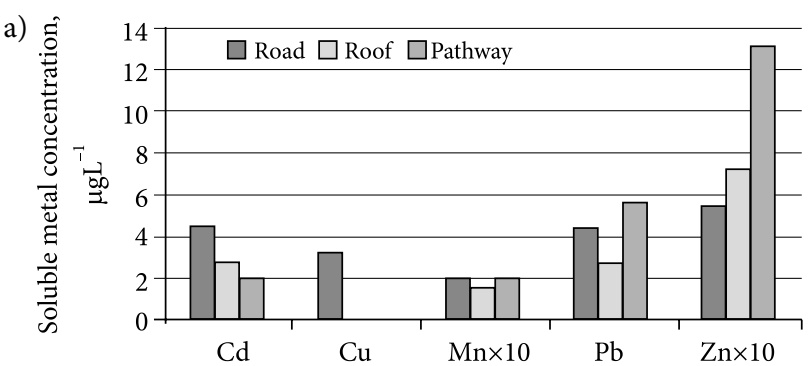

b)

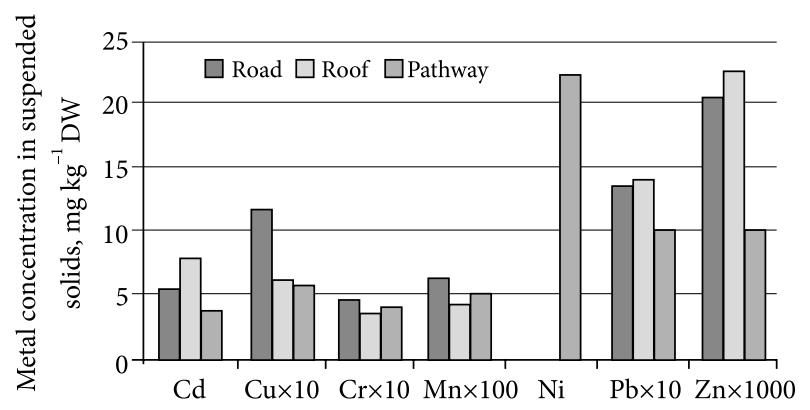

Fig. 3. Average concentration of the trace metals detected in soluble (a) and insoluble (b) forms in urban storm water runoff samples from the investigated sites

Table 6. Free ion activity and fraction bound to colloid (FA) of trace metals and macro elements in urban storm water runoff (USWR) from different surfaces, calculated by WHAM. [FA-M], concentration of M, trace metals and macro elements, bound to fulvic acids, FA. [ ] tot. diss., total dissolved concentration of trace metals and macro elements

\begin{tabular}{|c|c|c|c|c|c|c|c|c|}
\hline & \multicolumn{4}{|c|}{$\mathrm{Mg}$} & \multicolumn{4}{|c|}{$\mathrm{K}$} \\
\hline & $\begin{array}{c}{\left[\mathrm{Mg}^{2+}\right]} \\
\left(\mathrm{mol} \mathrm{L}^{-1}\right)\end{array}$ & $\begin{array}{l}{[\mathrm{FA}-\mathrm{Mg}]} \\
\left(\mathrm{mol} \mathrm{L}^{-1}\right)\end{array}$ & $\begin{array}{l}{\left[\mathrm{Mg}^{2+}\right] /} \\
{[\mathrm{Mg}]_{\text {tot diss }}}\end{array}$ & $\begin{array}{l}{[\mathrm{FA}-\mathrm{Mg}] /} \\
{[\mathrm{Mg}]_{\text {tot diss }}}\end{array}$ & $\begin{array}{c}{\left[\mathrm{K}^{+}\right]} \\
\left(\mathrm{mol} \mathrm{L}^{-1}\right)\end{array}$ & $\begin{array}{c}{[\mathrm{FA}-\mathrm{K}]} \\
\left(\mathrm{mol} \mathrm{L}^{-1}\right)\end{array}$ & $\begin{array}{l}{\left[\mathrm{K}^{+}\right] /} \\
{[\mathrm{K}]_{\text {tot diss }}}\end{array}$ & $\begin{array}{l}{[\mathrm{FA}-\mathrm{K}] /} \\
{[\mathrm{K}]_{\text {tot diss }}}\end{array}$ \\
\hline Roof & $3.62 \times 10^{-6}$ & $4.79 \times 10^{-8}$ & 0.89 & 0.01 & - & - & - & - \\
\hline Pathway & $2.36 \times 10^{-5}$ & $8.38 \times 10^{-7}$ & 0.90 & 0.03 & $4.42 \times 10^{-5}$ & $8.00 \times 10^{-7}$ & 0.97 & 0.02 \\
\hline \multirow[t]{3}{*}{ Road } & $2.27 \times 10^{-5}$ & $1.61 \times 10^{-6}$ & 0.93 & 0.07 & $1.22 \times 10^{-5}$ & $5.42 \times 10^{-7}$ & 0.99 & 0.04 \\
\hline & \multicolumn{4}{|c|}{$\mathrm{Ca}$} & \multicolumn{4}{|c|}{$\mathrm{Mn}$} \\
\hline & $\begin{array}{c}{\left[\mathrm{Ca}^{2+}\right]} \\
\left(\mathrm{mol} \mathrm{L}^{-1}\right)\end{array}$ & $\begin{array}{l}{[\mathrm{FA}-\mathrm{Ca}]} \\
\left(\mathrm{mol} \mathrm{L}^{-1}\right)\end{array}$ & $\begin{array}{c}{\left[\mathrm{Ca}^{2+}\right] /} \\
{[\mathrm{Ca}]_{\text {tot diss }}}\end{array}$ & $\begin{array}{l}{[\mathrm{FA}-\mathrm{Ca}] /} \\
{[\mathrm{Ca}]_{\text {tot diss }}}\end{array}$ & $\begin{array}{c}{\left[\mathrm{Mn}^{2+}\right]} \\
\left(\mathrm{mol} \mathrm{L}^{-1}\right)\end{array}$ & $\begin{array}{l}{[\mathrm{FA}-\mathrm{Mn}]} \\
\left(\mathrm{mol} \mathrm{L}{ }^{-1}\right)\end{array}$ & $\begin{array}{l}{\left[\mathrm{Mn}^{2+}\right] /} \\
{[\mathrm{Mn}]_{\text {tot diss }}}\end{array}$ & $\begin{array}{l}{[\mathrm{FA}-\mathrm{Mn}] /} \\
{[\mathrm{Mn}]_{\text {tot diss }}}\end{array}$ \\
\hline Roof & $2.55 \times 10^{-4}$ & $4.26 \times 10^{-6}$ & 0.89 & 0.01 & $2.55 \times 10^{-4}$ & $7.98 \times 10^{-8}$ & 0.64 & 0.29 \\
\hline Pathway & $1.49 \times 10^{-4}$ & $6.86 \times 10^{-6}$ & 0.89 & 0.04 & $1.49 \times 10^{-4}$ & $2.10 \times 10^{-7}$ & 0.42 & 0.55 \\
\hline \multirow[t]{3}{*}{ Road } & $3.25 \times 10^{-5}$ & $3.07 \times 10^{-6}$ & 0.91 & 0.09 & $3.25 \times 10^{-5}$ & $2.58 \times 10^{-7}$ & 0.24 & 0.76 \\
\hline & \multicolumn{4}{|c|}{$\mathrm{Cu}$} & \multicolumn{4}{|c|}{$\mathrm{Zn}$} \\
\hline & $\begin{array}{c}{\left[\mathrm{Cu}^{2+}\right]} \\
\left(\mathrm{mol} \mathrm{L}^{-1}\right)\end{array}$ & $\begin{array}{r}{[\mathrm{FA}-\mathrm{Cu}]} \\
\left(\mathrm{mol} \mathrm{L}^{-1}\right)\end{array}$ & $\begin{array}{l}{\left[\mathrm{Cu}^{2+}\right] /} \\
{[\mathrm{Cu}]_{\text {tot diss }}}\end{array}$ & $\begin{array}{l}{[\mathrm{FA}-\mathrm{Cu}] /} \\
{[\mathrm{Cu}]_{\text {tot diss }}}\end{array}$ & $\begin{array}{c}{\left[\mathrm{Zn}^{2+}\right]} \\
\left(\mathrm{mol} \mathrm{L}^{-1}\right)\end{array}$ & $\begin{array}{l}{[\mathrm{FA}-\mathrm{Zn}]} \\
\left(\mathrm{mol} \mathrm{L}^{-1}\right)\end{array}$ & $\begin{array}{c}{\left[\mathrm{Zn}^{2+}\right] /} \\
{[\mathrm{Zn}]_{\text {tot diss }}}\end{array}$ & $\begin{array}{l}{[\mathrm{FA}-\mathrm{Zn}] /} \\
{[\mathrm{Zn}]_{\text {tot diss }}}\end{array}$ \\
\hline Roof & - & - & - & - & $7.5 \times 10^{-7}$ & $2.78 \times 10^{-7}$ & 0.68 & 0.25 \\
\hline Pathway & - & - & - & - & $9.93 \times 10^{-7}$ & $9.37 \times 10^{-7}$ & 0.49 & 0.46 \\
\hline \multirow[t]{3}{*}{ Road } & $7.52 \times 10^{-11}$ & $5.01 \times 10^{-8}$ & 0.0 & 1.0 & $2.5 \times 10^{-7}$ & $5.53 \times 10^{-7}$ & 0.30 & 0.67 \\
\hline & \multicolumn{4}{|c|}{$\mathrm{Cd}$} & \multicolumn{4}{|c|}{$\mathrm{Pb}$} \\
\hline & $\begin{array}{c}{\left[\mathrm{Cd}^{2+}\right]} \\
\left(\mathrm{mol} \mathrm{L}^{-1}\right)\end{array}$ & $\begin{array}{l}{[\mathrm{FA}-\mathrm{Cd}]} \\
\left(\mathrm{mol} \mathrm{L}^{-1}\right)\end{array}$ & $\begin{array}{l}{\left[\mathrm{Cd}^{2+}\right] /} \\
{[\mathrm{Cd}]_{\text {tot diss }}}\end{array}$ & $\begin{array}{l}{[\mathrm{FA}-\mathrm{Cd}] /} \\
{[\mathrm{Cd}]_{\text {tot diss }}}\end{array}$ & $\begin{array}{c}{\left[\mathrm{Pb}^{2+}\right]} \\
\left(\mathrm{mol} \mathrm{L}^{-1}\right)\end{array}$ & $\begin{array}{l}{[\mathrm{FA}-\mathrm{Pb}]} \\
\left(\mathrm{mol} \mathrm{L}^{-1}\right)\end{array}$ & $\begin{array}{l}{\left[\mathrm{Pb}^{2+}\right] /} \\
{[\mathrm{Pb}]_{\text {tot diss }}}\end{array}$ & $\begin{array}{l}{[\mathrm{FA}-\mathrm{Pb}] /} \\
{[\mathrm{Pb}]_{\text {tot diss }}}\end{array}$ \\
\hline Roof & $1.91 \times 10^{-8}$ & $2.89 \times 10^{-9}$ & 0.80 & 0.12 & $9.36 \times 10^{-10}$ & $2.67 \times 10^{-3}$ & 0.0 & 0.92 \\
\hline Pathway & $1.3 \times 10^{-8}$ & $4.72 \times 10^{-9}$ & 0.69 & 0.25 & $7.52 \times 10^{-10}$ & $5.6 \times 10^{-3}$ & 0.0 & 0.97 \\
\hline Road & $2.27 \times 10^{-8}$ & $1.8 \times 10^{-8}$ & 0.55 & 0.44 & $2.36 \times 10^{-10}$ & $4.5 \times 10^{-3}$ & 0.0 & 0.98 \\
\hline
\end{tabular}




\subsection{Metal speciation in USWR using WHAM}

WHAM modelling results showed a variability in the speciation behaviour of trace metals ( $\mathrm{Cd}, \mathrm{Mn} \mathrm{Pb}$, and $\mathrm{Zn}$ ) between the sites, whereas major cation ( $\mathrm{Ca}, \mathrm{Mg}$, and $\mathrm{K}$ ) speciation was not substantially affected by the different USWR types (Table 6). In all the analysed USWR types, the major cations $(\mathrm{Ca}, \mathrm{Mg}, \mathrm{K})$ were characterized by the predominance of free metal ions forms, with a value of free ion activity calculated in the range $89-99 \%$ of the total dissolved elements (Table 6). Speciation model results for $\mathrm{Pb}$ and $\mathrm{Cu}$ showed their affinity to form complexes. In all the USWR types, the predominant $\mathrm{Pb}$ species (with more than $90 \%$ of the total dissolved $\mathrm{Pb}$ ) is the $\mathrm{Pb}$-fulvic acid complex. In addition, compared to the total dissolved concentration, the concentration of free $\mathrm{Pb}^{2+}$ activity is negligible. In road USWR modelling $\mathrm{Cu}-\mathrm{FA}$ were found to be the dominant complexes, being up to $99 \%$ of the total dissolved $\mathrm{Cu}$.

Of all the modelled water-types, road USWR showed the highest ratio between the free major cation activity and total dissolved concentration; conversely the lowest ratio of free $\mathrm{Cd}^{2+}$ and $\mathrm{Zn}^{2+}$ activity was noticed with a value of 55 and $30 \%$ of total dissolved $\mathrm{Cd}$ and $\mathrm{Zn}$, respectively. Roof USWR modelling showed the highest ratio of free $\mathrm{Mn}^{2+}, \mathrm{Zn}^{2+}$, and $\mathrm{Cd}^{2+}$ activity with a value of 64,68 and $80 \%$ of total dissolved $\mathrm{Mn}, \mathrm{Zn}$ and $\mathrm{Cd}$, respectively. The highest fraction of $\mathrm{Pb}$ and $\mathrm{Zn}$ bound to $\mathrm{FA}$ was found in the USWR from the pathway. The Pb-FA and $\mathrm{Zn}-\mathrm{FA}$ complexes were calculated to be from 19.6 to $52.3 \%$ and from 41 to $70.3 \%$ higher than $\mathrm{Pb}-\mathrm{FA}$ and $\mathrm{Zn}-\mathrm{FA}$ complexes in the road and roof USWR modelling, respectively. The metal fulvic acid complexes of Mn were $62 \%$ higher in the modelling of USWR from the pathway compared to the roof USWR whereas they were $18.6 \%$ less than the road USWR.

Comparisons of USWR modelling results showed that the USWR types characterized by a higher $\mathrm{pH}$ or DOC concentration produced a higher fraction of metals bound to FA. A higher fraction of Cd (38.8\%), Mn (62\%), $\mathrm{Pb}(52.3 \%), \mathrm{Zn}$ (70.3\%) bound to FA was calculated in the modelling of USWR from the pathway compared to the roof USWR. The pathway USWR exhibited a slightly higher $\mathrm{pH}$ and a higher DOC (about 47\%) concentration than the roof ones. In the road USWR modelling, the $\mathrm{Cd}, \mathrm{Mn}, \mathrm{Pb}, \mathrm{Zn}$-FA complexes were from about 40 to $80 \%$ higher than the ones calculated for the roof USWR. USWR from the road had a higher $\mathrm{pH}$ (about 14\%) and an almost equal DOC concentration compared to the one from the roof. Investigating the complexation of $\mathrm{Cd}, \mathrm{Ni}$, and $\mathrm{Zn}$ as a function of DOC concentrations in groundwater for a range of $\mathrm{pH}$ values, Christensen, J. B. and Christensen, T. H. (2000) found that DOC-metal complexing increased with increasing $\mathrm{pH}$.

\section{Conclusions}

1. The presence of trace metals in the USWR from the investigated sites was likely to be due to non-point source pollution such as atmospheric deposition as well as local pollution sources such as the erosion of building materials and traffic activities. The high concentrations of $\mathrm{Cd}$, $\mathrm{Pb}$, and $\mathrm{Zn}$ detected in the USWR from the roof and road surfaces may be attributed to the corrosion of galvanized steel materials (e.g. steel sheets, downspouts, gutters and safety barriers). Correlations ( $\mathrm{p}<0.01, \mathrm{p}<0.05)$ between these metals were found.

2. Analyses of metals both in SS and the dissolved form showed the predominance of the SS-bound fraction of all the detected elements with more than $80 \%$ of the total amount measured, irrespective of the water quality characteristics (e.g. pH, DOC, SS) and types of surface area. The partitioning coefficient $(\log \mathrm{Kd})$ of trace metals decreases in the order $\mathrm{Zn}>\mathrm{Cu} \approx \mathrm{Mn} \approx \mathrm{Pb}>>\mathrm{Cd}$.

3. The concentration of trace metals $(\mathrm{Cd}, \mathrm{Cr}, \mathrm{Cu}, \mathrm{Pb}$, $\mathrm{Ni}$, and $\mathrm{Zn}$ ) in the dissolved form did not exceed the $\mathrm{Li}-$ thuanian Maximum Allowable Concentration (MAC) limits in all the USWR samples. Trace metals such as $\mathrm{Cr}$ and Ni were not detected in the soluble phase. The concentration of $\mathrm{Cd}, \mathrm{Cu}, \mathrm{Pb}$ and $\mathrm{Zn}$ in the dissolved form was far lower (up to one order of magnitude) than the MAC limits of these metals for the environment.

4. WHAM modelling results showed a variability in the speciation behaviour of trace metals $(\mathrm{Cd}, \mathrm{Mn}, \mathrm{Pb}$, and $\mathrm{Zn}$ ) between the investigated sites, whereas major cation ( $\mathrm{Ca}, \mathrm{Mg}, \mathrm{K}$ ) speciation was not substantially affected by the different USWR types. $\mathrm{Ca}, \mathrm{Mg}$, and $\mathrm{K}$ were characterized by the predominance of free metal ion forms, being from 89 to $99 \%$ of the total dissolved elements. USWR types characterized by a higher $\mathrm{pH}$ or DOC concentration produced a higher fraction of trace metals bound to FA. A higher fraction of $\mathrm{Cd}(38.8 \%), \mathrm{Mn}(62 \%), \mathrm{Pb}(52.3 \%)$, and $\mathrm{Zn}(70.3 \%)$ bound to FA was calculated in the modelling of USWR from the pathway compared to the roof USWR. In the road USWR modelling, the $\mathrm{Cd}, \mathrm{Mn}, \mathrm{Pb}$, $\mathrm{Zn}-\mathrm{FA}$ complexes were about 40 to $80 \%$ higher than the ones calculated in the roof USWR.

5. Since the studied metals were mainly related to SS, the removal of SS can be an effective method for reducing metal concentrations in USWR. For example, the adoption of best management practices (BMPs) that employ sedimentation or filtration (e.g. porous pavement, wet and dry detention ponds) may be efficient in abating the flow of metals loads to receiving water basins.

6. Since roof USWR analysis exhibited the highest concentrations of $\mathrm{Zn}$ and $\mathrm{Cd}$ in SS (from 10 to 55\% and 30 to $50 \%$ higher than the road and pathway levels, respectively) and the speciation modelling showed the highest ratio of free ion activity to total dissolved zinc (68\%) and 
cadmium (80\%), if a change in water chemical parameters occurs, the release of metals from SS may pose a problem because of the strong bioavailability of the dissolved metal fraction.

\section{Acknowledgements}

We gratefully acknowledge the help of our colleagues from the Department of Environmental Protection at Vilnius Gediminas Technical University for the chemical analyses, Justina Vaiciute for the legal advice about environmental legislation, as well as Dr. Rodolfo Venerucci for his assistance in statistical analysis. The data and information provided by the Lithuanian Hydrometeorological Service are greatly acknowledged.

\section{References}

Adachi, K.; Tainosho, Y. 2004. Characterization of heavy metal particles embedded in tire dust, Environment International 30(8): 1009-1017.

http://dx.doi.org/10.1016/j.envint.2004.04.004

Allison, J. D.; Allison, T. L. 2005. Partition coefficients for metals in surface water, soil, and waste. Prepared for U.S. EPA Office of Research and Development: Washington, DC, EPA/600/R-05. 74 p.

Baltrenaite, E.; Butkus, D.; Booth, C. A. 2010. Comparison of tree-ring sampling methods for trace metal analysis, Journal of Environmental Engineering and Landscape Management 18(3): 170-178. http://dx.doi.org/10.3846/jeelm.2010.20

Baltrènas, P.; Kaziukonienė, D.; Kvasauskas, M. 2004. Air pollution at parking-lots of Vilnius, Journal of Environmental Engineering and Landscape Management 12(1): 38-43. http://dx.doi.org/10.1080/16486897.2004.9636813

Bricker, O. P. 1999. An overview of the factors involved in evaluating the geochemical effects of highway runoff on the environment, U.S. Geological Survey Open File Report 98-630. $28 \mathrm{p}$.

Brown, J. N.; Peake, B. M. 2006. Sources of heavy metals and polycyclic aromatic hydrocarbons in urban stormwater runoff, Science of the Total Environment 359(1): 145-155. http://dx.doi.org/10.1016/j.scitotenv.2005.05.016

Butkus, D.; Baltrenaite, E. 2007. Accumulation of heavy metals in tree seedling from soil amended with sewage sludge, Ekologija 53(4): 68-76.

Chang, M.; McBroom, M. W.; Scott, B. R. 2004. Roofing as a source of nonpoint water pollution, Journal of environmental management 73(4): 307-315.

http://dx.doi.org/10.1016/j.jenvman.2004.06.014

Christensen, J. B.; Christensen, T. H. 2000. The effect of $\mathrm{pH}$ on the complexation of $\mathrm{Cd}, \mathrm{Ni}$ and $\mathrm{Zn}$ by dissolved organic carbon from leachate-polluted groundwater, Water Research 34: 3743-3745.

http://dx.doi.org/10.1016/S0043-1354(00)00127-5

Ciffroy, P.; Garnier, J. M.; Benyahya, L. 2003. Kinetic partitioning of $\mathrm{Co}, \mathrm{Mn}, \mathrm{Cs}, \mathrm{Fe}, \mathrm{Ag}, \mathrm{Zn}$ and $\mathrm{Cd}$ in fresh waters (Loire) mixed with brackish waters (Loire estuary): experimental and modelling approaches, Marine Pollution Bulletin 46(5): 625-641. http://dx.doi.org/10.1016/S0025-326X(02)00517-9
Comber, S.; Georges, K. 2008. Tiered approach to assessment of metal compliance in surface waters, Environment Agency [online], [cited 9 June 2013]. Available from Internet: http:// www.wfduk.org/sites/default/files/Media/Environmental standards/Tiered approach metal compliance.pdf

Dierkes, C.; Göbel, P.; Lohmann, M.; Coldewey, W. G. 2005. Development and investigation of a pollution control pit for treatment of stormwater from metal roofs and traffic areas, Urban Drainage 54(6): 291-298.

Dudutytė, Z; Manusadžianas, L.; Ščeponavičiūtè, R. 2007. Report on dangerous substances in the aquatic environment of Lithuania. Prepared within the project Screening of dangerous substances in the aquatic environment of Lithuania. Vilnius, Lithuania. $53 \mathrm{p}$.

Dwane, G. C.; Tipping, E. 1998. Testing a humic speciation model by titration of copper-amended natural waters, Environmental International 24(5/6): 609-616. http://dx.doi.org/10.1016/S0160-4120(98)00046-4

European Commission (EC). 2008. Directive 2008/105/EC of the European Parliament and of the Council of 16 December 2008 on environmental quality standards in the field of water policy, Official Journal of the European Union L348.

Gnecco, I.; Sansalone, J. J.; Lanza, L. G. 2008. On the kinetics of pollutants in storm water runoff, in 11 ICUD - 11th International Conference on Urban Drainage, 31 August - 5 September, 2008, Edinburgh, Scotland, UK [online], [cited 2 May 2014]. Available from Internet: http://web.sbe.hw.ac.uk/ staffprofiles/bdgsa/11th_International_Conference_on_Urban_Drainage_CD/ICUD08/pdfs/587.pdf

Göbel, P.; Dierkes, C.; Coldewey, W. G. 2007. Storm water runoff concentration matrix for urban areas, Journal of Contaminant Hydrology 91: 26-42.

http://dx.doi.org/10.1016/j.jconhyd.2006.08.008

Herngren, L.; Goonetilleke, A.; Ayoko, G. A. 2005. Understanding heavy metal and suspended solids relationships in urban stormwater using simulated rainfall, Journal of Environmental Management 76(2): 149-158. http://dx.doi.org/10.1016/j.jenvman.2005.01.013

ISO 10523:2008. Water quality - Determination of $p H$. International Organization for Standardization, Geneva, Switzerland, 2008. $13 \mathrm{p}$.

ISO 11047:1998. Soil quality - Determination of cadmium, chromium, cobalt, copper, lead, manganese, nickel and zinc in acqua regia extracts of soil - Flame and electrothermal atomic absorption spectrometric methods. International Organization for Standardization, Geneva, Switzerland, 1998. 18 p.

ISO 5667-1:2006. Water quality - Sampling - Part 1: Guidance on the design of sampling programmes and sampling techniques. International Organization for Standardization, Geneva, Switzerland, 2006. $31 \mathrm{p}$.

ISO 5667-3:2006. Water quality - Sampling - Part 3: Guidance on the preservation and handling of water samples. International Organization for Standardization, Geneva, Switzerland, 2006. $42 \mathrm{p}$.

ISO 7888: 1985. Water quality - Determination of electrical conductivity. International Organization for Standardization, Geneva, Switzerland, 1985. 6 p.

ISO 7980:1986. Water quality - Determination of calcium and magnesium - Atomic absorption spectrometric method. International Organization for Standardization, Geneva, Switzerland, 1986. 3 p. 
ISO 8288:1986. Water quality - Determination of cobalt, nickel, copper, zinc, cadmium and lead - Flame atomic absorption spectrometric methods. International Organization for Standardization, Geneva, Switzerland, 1986. 11 p.

ISO 9174:1998. Water quality - Determination of chromium Atomic absorption spectrometric methods. International Organization for Standardization, Geneva, Switzerland, 1998. $10 \mathrm{p}$.

ISO 9964-2:1993. Water quality - Determination of sodium and potassium. Part 2: Determination of potassium by atomic absorption spectrometry. International Organization for Standardization, Geneva, Switzerland,1993. 4 p.

Jarasuniene, A. 2010. The solutions to vehicle traffic organisation problems in Vilnius, in Proceedings of the 10th International Conference "Reliability and Statistics in Transportation and Communication" (RelStat'10), 20-23 October 2010, Riga, Latvia, 79-83.

Karlavičienè, V.; Švedienè, S.; Marčiulionienè, D. E.; Randerson, P.; Rimeika, M.; Hogland, W. 2009. The impact of storm water runoff on a small urban stream, Journal of Soils and Sediments 9(1): 6-12. http://dx.doi.org/10.1007/s11368-008-0038-9

Kayhanian, M.; Stransky, C.; Bay, S.; Lau, S. L.; Stenstrom, M. K. 2008. Toxicity of urban highway runoff with respect to storm duration, Science of the Total Environment 389(2): 386-406. http://dx.doi.org/10.1016/j.scitotenv.2007.08.052

Lamprea, K.; Ruban, V. 2008. Micro pollutants in atmospheric deposition, roof runoff and storm water runoff of a suburban Catchment in Nantes, France, in 11 ICUD - 11th International Conference on Urban Drainage, 31 August - 5 September, 2008, Edinburgh, Scotland, UK [online], [cited 2 May 2014]. Available from Internet: http://web.sbe.hw.ac.uk/staffprofiles/ bdgsa/11th_International_Conference_on_Urban_Drainage_CD/ICUD08/pdfs/194.pdf

Milukaite, A.; Sakalys, J.; Kvietkus, K.; Vosyliene, M. Z.; Kazlauskiene, N.; Karlaviciene, V. 2010. Physico-chemical and ecotoxicological characterizations of urban storm water runoff, Polish Journal of Environmental Studies 19(6): 1279-1285.

Milukaite, A.; Valiulis, D.; Sakalys, J. 2008. Fluxes and loading of heavy metals, benzo[a]pyrene and oil products in Vilnius city, Water Air Soil Pollution 8: 485-494.

http://dx.doi.org/10.1007/s11267-008-9181-y

Ogburn, O.; Pitt, R.; Clark, S. 2012. Pollutant releases from gutter and piping materials into urban stormwater runoff, in Proceedings of World Environmental and Water Resources Congress 2012: Crossing Boundaries, Albuquerque, 20-24 May 2012, New Mexico, US, 3674-3685.

http://dx.doi.org/10.1061/9780784412312.369

Peijnenburg, W. J. G. M.; Jager, T. 2003. Monitoring approaches to assess bioaccessibility and bioavailability of metals: matrix issues, Ecotoxicology and Environmental Safety 56(1): 63-77. http://dx.doi.org/10.1016/S0147-6513(03)00051-4

Pitt, R.; Field, R.; Lalor, M.; Brown, M. 1995. Urban storm-water toxic pollutants: assessment, sources, and treatability, Water Environment Research 67(3): 260-275. http://dx.doi.org/10.2175/106143095X131466

Prestes, E. C.; dos Anjos, V. E.; Sodrè, F. F.; Grassi, M. T. 2006. Copper, lead and cadmium loads and behaviour in urban stormwater runoff in Curitiba, Brazil, Journal of Brazilian Chemical Society 17(1): 53-60.

http://dx.doi.org/10.1590/S0103-50532006000100008
Pundytė, N.; Baltrenaitè, E.; Pereira, P.; Paliulis, D. 2011. Anthropogenic effect on heavy metals and macronutrients accumulation in soil and wood of Pinus sylvestris L., Journal of Environmental Engineering and Landscape Management 19(1): 33-43. http://dx.doi.org/10.3846/16486897.2011.557473

Rocher, V.; Azimi, S.; Gasperi, J.; Beuvin, L.; Muller, M.; Moilleron, R.; Chebbo, G. 2004. Hydrocarbons and metals in atmospheric deposition and roof runoff in central Paris, Water, Air, and Soil Pollution 159(1): 67-86. http://dx.doi.org/10.1023/B:WATE.0000049165.12410.98

Rule, K. L.; Comber, S. D. W.; Ross, D.; Thomton, A.; Makropoulos, C. K.; Rautiu, R. 2006. Diffuse sources of heavy metals entering an urban wastewater catchment, Chemosphere 63(1): 64-72. http://dx.doi.org/10.1016/j.chemosphere.2005.07.052

Sabin, L. D.; Lim, J. H.; Stolzenbach, K. D.; Schiff, K. C. 2005. Contribution of trace metals from atmospheric deposition to stormwater runoff in a small impervious urban catchment, Water Research 39(16): 3929-3937. http://dx.doi.org/10.1016/j.watres.2005.07.003

Sansalone, J.; Ying, G. 2008. Partitioning and granulometric distribution of metal leachate from urban traffic dry deposition particulate matter subject to acidic rainfall and runoff retention, Water Research 42(15): 4146-4162. http://dx.doi.org/10.1016/j.watres.2008.06.013

Shaw, S. B.; Walter, M. T.; Steenhius, T. S. 2006. A physical model of particulate wash-off from rough impervious surface, Journal of Hydrology 327: 618-626. http://dx.doi.org/10.1016/j.jhydrol.2006.01.024

Spurlock, F. 1999. DPR SOP FSWA008.00 Sampling for surface water runoff in agricultural fields [online], [cited 2 January 2013]. Available from Internet: http://www.cdpr.ca.gov/docs/ emon/pubs/sops/fswa008.pdf

Taraškevičius, R.; Zinkute, R.; Jankauskaitė, M. 2008. Differences of Vilnius topsoil contamination in Neris River valley due to anthropogenic factors, Geologija 50 3(63): 135-142.

Tiefenthaler, L. L.; Stein, E. D.; Schiff, K. C. 2008. Watershed and land use-based sources of trace metals in urban storm water, Environmental Toxicology and Chemistry 27(2): 277-287. http://dx.doi.org/10.1897/07-126R.1

Tipping, E. 1994. WHAM - a chemical equilibrium model and computer code for waters, sediments and soils incorporating a discrete-site/electrostatic model for ion-binding by humic substances, Computers and Geosciences 20: 973. http://dx.doi.org/10.1016/0098-3004(94)90038-8

Tipping, E.; Lofts, S.; Sonke, J. E. 2011. Humic ion-binding model VII: a revised parameterisation of cation-binding by humic substances, Environmental Chemistry 8: 225-235. http://dx.doi.org/10.1071/EN11016

Van Metre, P. C.; Mahler, B. J. 2003. The contribution of particles washed from rooftops to contaminant loading to urban streams, Chemosphere 52(10): 1727-1741. http://dx.doi.org/10.1016/S0045-6535(03)00454-5

Vasarevičius, S.; Mineikaite, A.; Vaitiekunas, P. 2010. Investigation into heavy metals in storm wastewater from Vilnius Zirmunai district and pollutantits spread model in Neris river, Journal of Environmental Engineering and Landscape Management 18(3): 242-249. http://dx.doi.org/10.3846/jeelm.2010.28

Weiss, J.; Hondzo, M.; Biesboer, D.; Semmens, M. 2006. Laboratory of heavy metal phytoremediation by three wetland macrophytes, International Journal of Phytoremediation 8: 245-259. http://dx.doi.org/10.1080/15226510600846798 
Wicke, D.; Cochrane, T. A.; O'Sullivan, A. 2012. Build-up dynamics of heavy metals deposited on impermeable urban surfaces, Journal of Environmental Management 113: 347-354. http://dx.doi.org/10.1016/j.jenvman.2012.09.005

Zinkutè, R.; Taraškevičius, R.; Želvys, T. 2011. Major elements as possible factors of trace element urban pedochemical anomalies, Central European Journal of Chemistry 9(2): 337-347.

http://dx.doi.org/10.2478/s11532-011-0012-z

Zavadskas, E. K.; Kaklauskas, A.; Šaparauskas, J.; Kalibatas, D. 2007. Vilnius urban sustainability assessment with an emphasis on pollution, Ecology 53: 64-72.

Enrico MANCINELLI. Master of Science in Civil Engineering (Università Politecnica delle Marche, 2013), Bachelor of Science in Civil Engineering (UNIVPM 2009). Research interests: trace metals in surface water, environmental protection.

Edita BALTRÉNAITÉ. Dr, Assoc. Prof. at the Department of Environmental Protection, Vilnius Gediminas Technical University (VGTU). She gained her Environmental Engineering and Landscape Management PhD in 2007, the diploma of the Associate Professor in 2010 from Vilnius Gediminas Technical University (Lithuania). Publications: author/co-author of approx. 38 scientific papers, participant of about 20 international conferences. She is a deputy member of the Management Committee of COST TD1107 Biochar as Option for Sustainable Resource Management and FA0905 Mineral-Improved Crop Production For Healthy Food and Feed. Main research visits: Latvian State Institute of Wood Chemistry under FP7 project The Implementation of Research Potential of the Latvian State Institute of Wood Chemistry in the European Research Area (WOOD-NET) (FP7-203459)); University of Ljubljana (Slovenia) under FP7 project SPIRIT Support of Public and Industrial Research Using Ion Beam Yechnology; short-term scientific mission at Norwegian University of Life Sciences, in the framework of COST 859 action Phytotechnologies to Promote Sustainable Land Use and Improve Food Safety (COST-859-STSM-04824). Research interests: biogeochemistry, phytogeochemistry, bioindication.

Pranas BALTRĖNAS. Dr Habil, Prof. and Head of the Department of Environmental Protection, Vilnius Gediminas Technical University (VGTU). Doctor Habil of Science (air pollution), Leningrad Civil Engineering Institute (Russia), 1989. Doctor of Science (Air Pollution) Ivanov Textile Institute (Russia), 1975. Employment: Professor (1990), Associate Professor (1985), Senior Lecturer (1975), Vilnius Civil Engineering Institute (VISI, now VGTU). Publications: author of 13 monographs, 24 study-guides, over 320 research papers and 67 inventions. Honorary awards and membership: prize-winner of the Republic of Lithuania (1994), a corresponding Member of the Ukrainian Academy of Technological Cybernetics, a full Member of International Academy of Ecology and Life Protection. Placements in Germany and Finland. Research interests: air pollution, pollutant properties, pollution control equipment and methods.

Dainius PALIULIS. Assoc. Prof. at the Department of Environmental Protection, Vilnius Gediminas Technical University (VGTU). Doctor of Science (air pollution) Vilnius Gediminas Technical University, 2000. Employment: Associate Professor (2006), Assistant (1997), Vilnius Gediminas Technical University. Publications: author of 1 monograph, 2 study-guides, over 50 research papers and 2 inventions. Research interests: air pollution, pollution control equipment and methods.

Giorgio PASSERINI. Assoc. Prof. at the Engineering Faculty of Marche Polytechnic University. MD in Electronic Engineering, PhD in Applied Physics. Employment: Associate Professor (2003), Researcher (1998) Marche Polytechnic University. Publications: 2 authored books, 4 edited books, over 90 papers. Research interests: air pollution; global warming assessment; energy conversion and management.

Åsgeir R. ALMÅS, Senior Research Scientist at the Norwegian University in Life Sciences, the Department of Environmental Sciences. Since 1999, he has been appointed as Post Doc, research scientist and project leader in several projects related to metal speciation in soil, sediments and fresh water and the impact of metal speciation on the soil biology. During most of his career he has used several techniques to investigate metal speciation in environmental samples using i.e. anodic stripping voltammetry (visiting scientist at Cornell University) WHAM/Model VI (Windermere Humic Aqueous Model, visiting scientist at the Centre of Ecology and Hydrology, UK) and DGT (diffusive gradients in thin films) technique. He has supervised a number of $\mathrm{PhD}$ and MSc students and collaborated with partners around the world. This has resulted in several peer-reviewed articles and contributions in conferences. His citation index at the moment is 9 . 